\title{
ANALYSIS THE EFFECT OF PRIMARY COIL LENGTH OF TRANSFORMER TO THE RESULTED ELECTROMOTIVE FORCE
}

\author{
Bowo Eko Cahyono*, Muhammad Syukron Ali, Supriyadi \\ Jurusan Fisika, FMIPA, Universitas Jember, Jl. Kalimantan 37 Jember 68125, Indonesia \\ *Corresponding Author Email: bowo_ec.fmipa@unej.ac.id
}

Received: 20 September 2018

Revised: 19 February 2019

Accepted: 30 April 2019

Published: 30 April 2019

SPEKTRA: Jurnal Fisika dan Aplikasinya

p-ISSN: 2541-3384

e-ISSN: 2541-3392

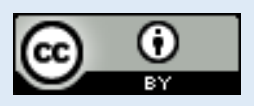

\begin{abstract}
The transformer is an electrical device that uses a principle of solenoid wrapped in kern, and there are usually two or more coils. Each coil of the transformer is electromagnetically connected. The transformer is made to fulfill the specific level of voltage required in the devices or systems that use alternating current electrical energy. For example, transformer tap change is design to have a different number of primary turns to produce a fixed output voltage; in the term, there is a changing in the input voltage. This research tries to analyze the effect of the length of the primary coil difference of transformer to the voltage resulted in the secondary coil. The objective of the study is producing a relationship of primary coil length variation to the resulting voltage. Variation of coil length is made from $1 \mathrm{~cm}$ to $15 \mathrm{~cm}$ with an interval of $1 \mathrm{~cm}$ coil length. The length of the secondary coil is also varied into $3 \mathrm{~cm}, 6 \mathrm{~cm}$, and $9 \mathrm{~cm}$. The test is performed by providing the same input voltage at each variation of the primary coil length and then measure the output voltage. The results show that the longer primary coil will produce a smaller output voltage in the secondary coil of the transformer. Based on the resulted graph, the relationship of the length variant of the primary coil is linear to the voltage measured in the secondary coil, with determination coefficient $\left(\mathrm{R}^{2}\right)$ of $0.9603,0.9775$, and 0.9822 respectively for the length of $3 \mathrm{~cm}, 6 \mathrm{~cm}$, and $9 \mathrm{~cm}$ of the secondary coil.
\end{abstract}

Keywords: transformer, primary coil, secondary coil, voltage 


\section{INTRODUCTION}

The magnitude of a magnetic field generated by a straight-line conductive wire, electricity according to the Ampere's Law states the line integral of the magnetic field intensity taken around the closed path is equal to the total current encircled by the area in the form of a closed track [1].

$$
\begin{aligned}
& \nabla x B=\mu_{0} J \\
& \int(\nabla x B) \cdot d a=\oint B \cdot d l=\mu_{0} \int J \cdot d a \\
& \oint B \cdot d l=\mu_{0} I_{\text {tot }}
\end{aligned}
$$

By using Biot-Savart law, the magnitude of the magnetic field is expressed by

$$
\begin{aligned}
& \mathrm{B} \oint \mathrm{dl}=\mu_{0} \mathrm{I}_{\text {tot }} \\
& \mathrm{B}=\frac{\mu_{0} \mathrm{I}}{2 \pi \mathrm{s}}
\end{aligned}
$$

Thus the magnitude of the magnetic field produced by straight wire has electricity depending on the amount of the electric current, and the distance from the current wire illustrations for Ampere can be seen in FIGURE 1.

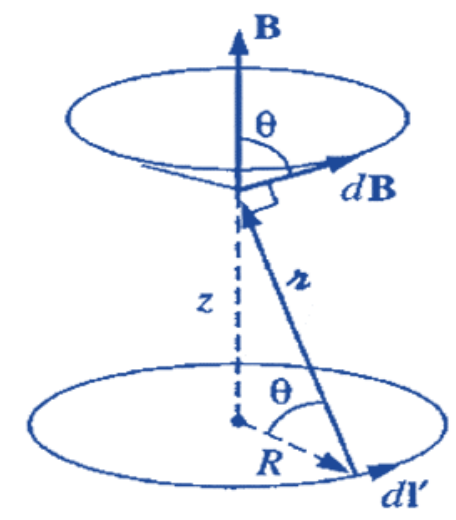

FIGURE 1. Magnetic Field in Circular Circular Wire [3].

When the conductor wire is charged in a circular shape, as shown in FIGURE 1 where $R$ is the radius and $z$ the distance from the center of the circle to the point of a review of the magnetic field, when the wire current, $I$, then

$$
\mathrm{B}_{(\mathrm{z})}=\frac{\mu_{0} \mathrm{I}}{4 \pi} \int \frac{\mathrm{dl} \prime}{\mathrm{r}^{2}} \cos \theta
$$

Because dl' circular with radius $\mathrm{R}$ then integral of $\mathrm{dl}$ ' to be $2 \pi \mathrm{R}$, with $\cos \theta$, and $\mathrm{r}^{2}$ constant so that the magnetic field of the wire passes

$$
\mathrm{B}_{(\mathrm{z})}=\frac{\mu_{0} \mathrm{I}}{2} \frac{\mathrm{R}^{2}}{\left(\mathrm{R}^{2}+\mathrm{z}^{2}\right)^{\frac{3}{2}}}
$$


The conductor wire that forms a circle if propagated in the form of a solenoid will produce a magnetic field higher than the number of turns it forms. Where the magnetic force line will be distributed evenly and parallel to the coil (FIGURE 2).

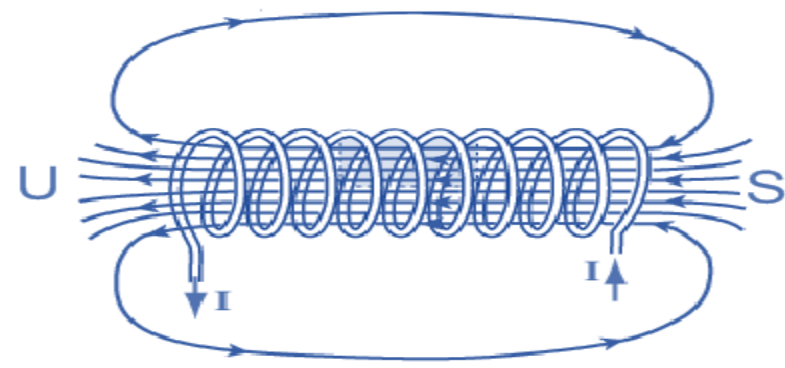

FIGURE 2. Magnetic Field at Solenoids [4].

Thus the great equation of the magnetic field on the solenoid is also affected by the number of turns, and is written as:

$$
\mathrm{B}=\mu_{0} \mathrm{I} \frac{\mathrm{N}}{\mathrm{L}}
$$

with $\frac{N}{L}=n$, so that the magnitude of the magnetic field produced by the solenoid coil becomes

$$
\mathrm{B}=\mathrm{n} \mu_{0} \mathrm{I}
$$

with $\mathrm{N}$ is the number of turns, $\mathrm{L}$ is the length of the solenoid, and $\mathrm{n}$ is the number of turns of long unity [5].

When two or more solenoids are wound in the shell, it forms a transformer that works based on the principle of electric and magnetic flux where between the solenoid and the other are not physically but electromagnetically connected. There are two types of solenoids in the transformer known as primary coils and secondary coils. Primary solenoid, referred to as the primary coil, is a solenoid, which is directly connected to the AC voltage source while the other solenoid which is not connected to the voltage source is called the secondary coil. The use of transformers, for example, in the transmission of electric power over long distances, besides that it is used for impedance coupling between source and load, and to inhibit direct current but still flow alternating current [6].

The transformer is significant in the use of alternating current electricity, where each electrical equipment has a specific voltage source to run it, such as the ITK 15-2 triode tube power supply that requires a voltage of 7.2 V and a current of $200 \mathrm{~A}$ [7]. The transformer can also be used as an electrodynamic energy producer in a wireless temperature monitoring system [8]. The lifetime of the transformer can be affected by the transient currents that appear on it due to the presence of electromechanical forces [9]. The amount of maximum current allowed in 
the transformer coil to avoid short circuit has been simulated [10]. Previous research on optimization of transformer performance due to energy losses due to flowing electric currents [11].

For the electric motor voltage source, the voltage generated depends on the rotation speed of the motor to measure the voltage generated by the electric motor fan installed on the motor, where the speed of the motor affects the rotational speed of the motor fan, so that it also affects the voltage generated [12]. Analyze the output voltage of a micro-hydro power generator against the frequency generator, where the frequency of the generator also affects the amount of central generated [13]. The voltage change resulting from the unstable rotation of the generator produces a transformer tap changer simulator that is a transformer simulator whose number of turns can be changed, so that if there is a voltage change to input the primary side it can be set on the tap changer to produce a fixed output voltage on the secondary coil [14]. The length of the coil also influences the effect of transformer voltage apart from the variation in the number of turns; this study analyzes the variation of the length of the primary coil to the electric force generated by the secondary coil on the transformer.

\section{RESEARCH METHOD}

The initial stage to be carried out in this study is to prepare the kocker (place of roll) from the primary coil and secondary coil. The number of turns on the primary coil is adjusted to the voltage used, which is $12 \mathrm{~V}$, and the number of turns per coil is 10 . So the number of turns in the primary coil made is 120 turns. As for the secondary coil, the number of turns is set at 300 turns. The length variation of the primary coil is $1 \mathrm{~cm}$ to $15 \mathrm{~cm}$ with a difference of $1 \mathrm{~cm}$ rolled on the kocker, while the secondary coil is $3 \mathrm{~cm}, 6 \mathrm{~cm}$, and $9 \mathrm{~cm}$ long. Furthermore, the primary and secondary coils are placed in the prepared area, as shown in FIGURE 3.

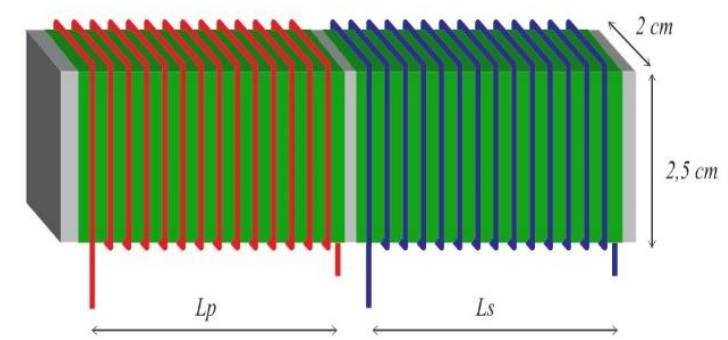

FIGURE 3. Coil Design

This study will measure the output or electromotive force (GGL) of the secondary coil in each variation of the primary coil. From these data, a graph of the relationship between the output voltage will be formed due to variations in the length of the primary coil so that it will be known the magnitude of the effect of the primary coil on the output voltage of the secondary coil. The measurement scheme carried out is shown in FIGURE 4. 


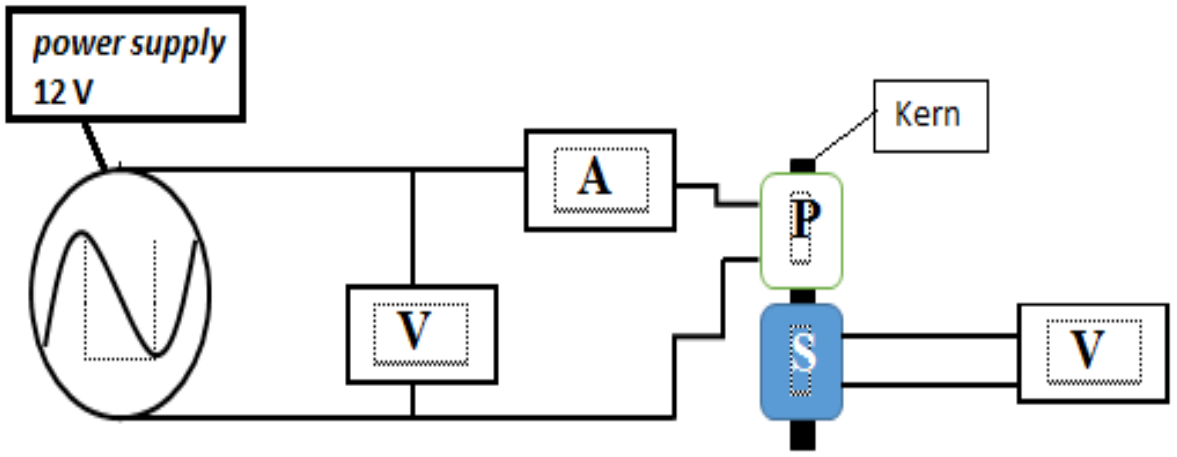

FIGURE 4. Design voltage measurements on primary and secondary coils

\section{RESULTS AND DISCUSSIONS}

Analysis of the effect of variations in the length of the primary coil is done by finding the output voltage generated on the secondary coil. From these results, a graph is formed of the relationship between the output voltage of the secondary coil to the variation of the length of the primary coil. The graph obtained is shown in FIGURE 5, FIGURE 6, and FIGURE 7.

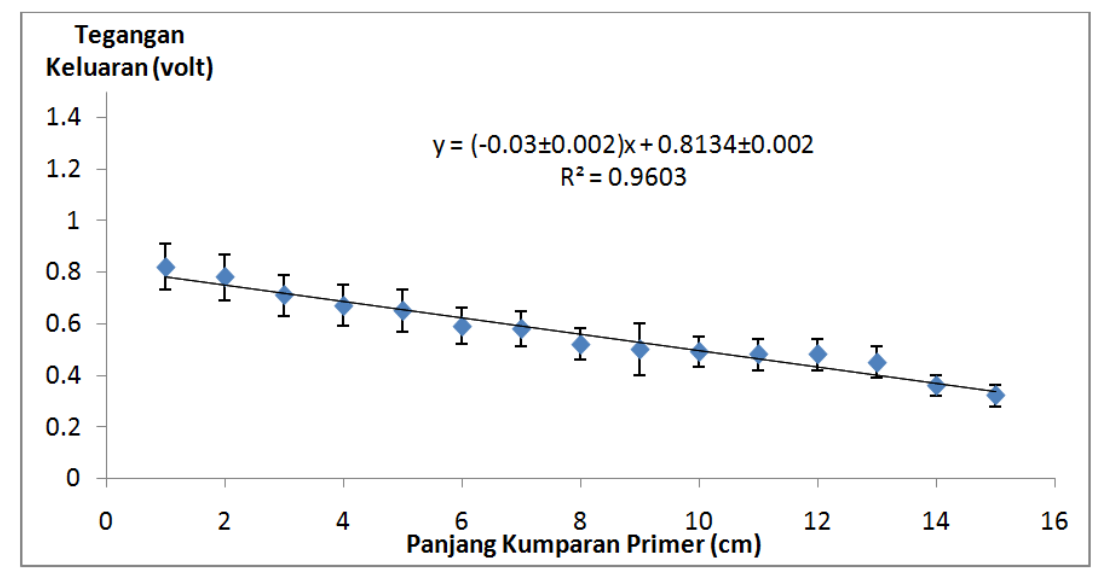

FIGURE 5. The Graph Relationship of Output Voltage to Variation Coil Length (secondary $3 \mathrm{~cm}$ ).

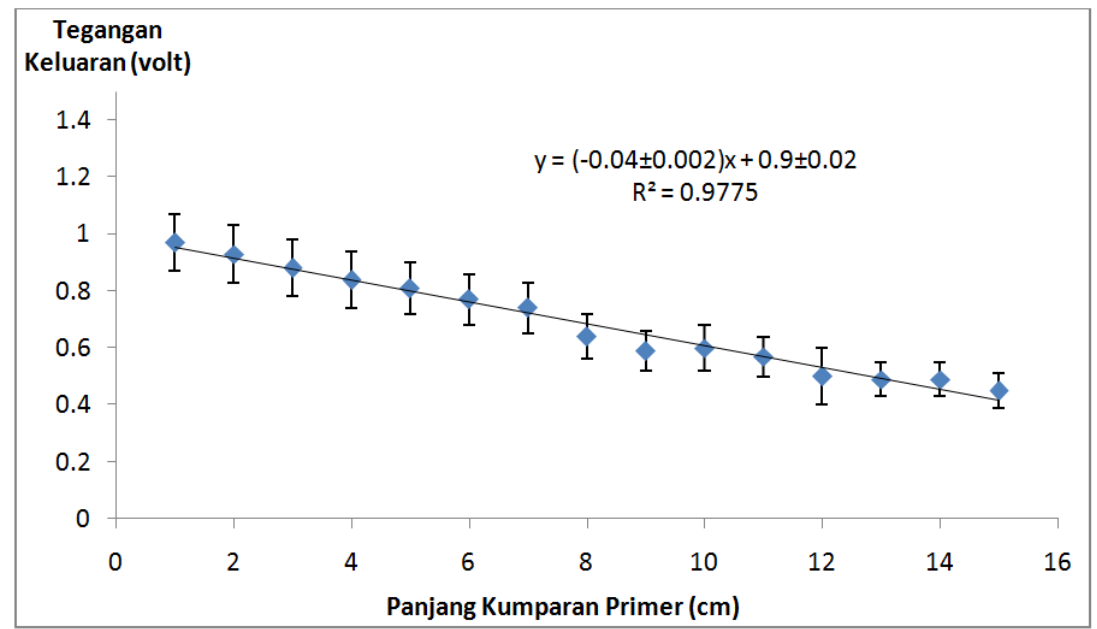

FIGURE 6. The Graph of Relationship of Output Voltage to Variation Coil Length (secondary $6 \mathrm{~cm}$ ). 


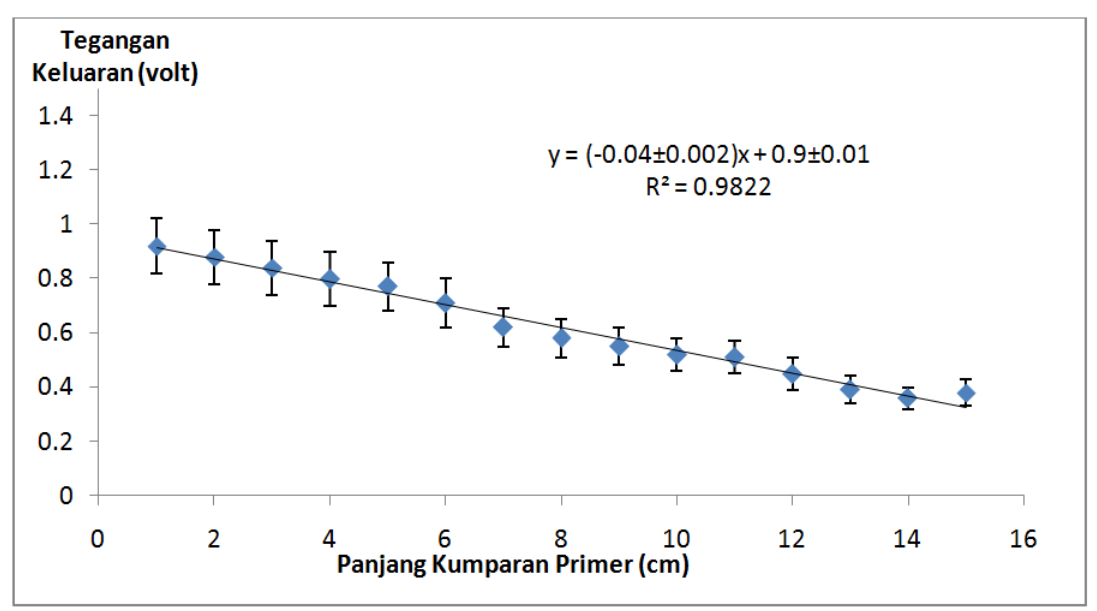

FIGURE 7. The Graph Relationship of Output Voltage to Variation Coil Length (secondary $9 \mathrm{~cm}$ ).

From these figures, can be seen the change in output voltage to the length of the primary coil is linear. When the length of the primary coil is increasingly enlarged, the voltage generated on the secondary coil will be smaller. This occurs in all three different secondary coil lengths. As for the accuracy of the distribution of data on the linearity of the trend line graphs can be seen from the large R-square value, that is if the value of R-square is close to one (1), the accuracy of data distribution is getting better more accurate. For the R-square graph of the relationship of the length of the primary coil to the output voltage of the secondary coil at the length of the secondary coil $3 \mathrm{~cm}$ is worth 0.9603 . This can be said that the distribution of data towards the linearity of trend line charts is quite accurate. Whereas the accuracy of the data distribution on the secondary coil length of $6 \mathrm{~cm}$ based on the trend line graph is also quite good, that is, the R-square shows a value of 0.9775 . Moreover, on the length of the secondary coil $9 \mathrm{~cm}$ is worth 0.9822 , this value indicates the accuracy of the distribution of data stuck to the graph of the graph is quite good.

\section{CONCLUSIONS}

This study has produced data on the output voltage changes in the secondary coils due to variations in the length of the primary coil, where the change in the size of the voltage gets smaller with the increasing length of the primary coil. Variations in the length of the primary coil have the same effect on the output voltage of the three different secondary coil lengths (3 $\mathrm{cm}, 6 \mathrm{~cm}$, and $9 \mathrm{~cm}$ ). Graphically the effect of the variation of the primary coil on the output voltage at each secondary coil length changes linearly with the magnitude of R square 0.9603 , 0.9775 , and 0.9822 . This value indicates that the pattern of data distribution towards the graph trend line is quite good, which is close to the value of 1.00 .

\section{REFERENCES}

[1] F. W. Sears, M. W. Zemansky, H. D. Young, "University Physics,” Addison-Wesley, 1987. 
[2] D. J. Griffiths, "Introduction to Electrodynamics," New Jersey: Prentice-Hall, 1999.

[3] H. D. Young, R. A. Freedman, L. Ford, "University Physics with Modern Physics 12th ed.," Addison Wesley, 2007.

[4] Hyperphysics, "Solenoid," 10 January 2017; http://hyperphysics.phyastr.gsu.edu/hbase/magnetic/solenoid.html.

[5] B. M. E. Jati, T. K. Priyambodo, "Fisika Dasar: Listrik-Magnet-Optika-Fisika Modern," Yogyakarta: CV. Andi Offset, 2010.

[6] W. Hayt, J Buck, “Engineering Electromagnetics, 8th ed.," McGraw-Hill Science, 2011.

[7] U. Margono, H. Sudarmanto, "Rancang Bangun Transformator 7, 2 V/200 A sebagai Catu Daya Filamen Tabung Trioda ITK 15-2 pada Generator Cockroft Walton MBE Lateks 300keV/20mA,” Tidak Diterbitkan, Proceeding, Yogyakarta: Batan, 2012.

[8] F. Khan, S. Razzaq, "Electrodynamic energy harvester for electrical transformer's temperature monitoring system," Sadhana, 40(7), 2001-2019, 2015.

[9] R. Guimarães, A. C. Delaiba, J. C. Oliveira, E. Saraiva, A. P. Rosentino, "Electromechanical Forces in Transformers Caused by Inrush Currents: An Analytical, Numerical and Experimental Approach," Journal of Control, Automation and Electrical Systems, 24(6), 2013.

[10] A. N. Novozhilov, V. N. Goryunov, T. A. Novozhilov, I. Y. Krylov, K. I. Nikitin, "Simulation of currents for relay protection of compound transformer windings from a coil short circuit," Russian Electrical Engineering, 84(4), 2013.

[11] A. M. Sobrinho, J. R. Camacho, J. A. Malagoli, A. C. F. Mamede, "Optimization of Losses in a Three-Phase Transformer Design with Inrush Current Analysis," Journal of Control, Automation and Electrical Systems, 29(6), 2018.

[12] F. Anggraini, A. Surtono, G. A. Pauz, "Pemanfaatan Energi Angin pada Sepeda Motor Bergerak untuk Menyalakan Lampu,” Jurnal Teori dan Aplikasi Fisika, 4(2), 2016.

[13] Mahalla, " Pengoprasian Motor Induksi sebagai Generator untuk Pembangkitan Listrik Tenaga Mikro Hydro (PLTMH),” Jurnal Litek, 10(2), 2013.

[14] Mulyadi, "Rancang Bangun Simulator Tap Charger Transformator sebagai Pengatur Tegangan Sistem Distribusi Tenaga Listrik," Laporan Penelitian, Bandung: Politeknik Negeri Bandung, 2012. 
